\title{
Polymyxin B
}

National Cancer Institute

\section{Source}

National Cancer Institute. Polymyxin B. NCI Thesaurus. Code C61894.

A mixture of the polypeptides polymyxins B1 and B2, both obtained from Bacillus polymyxa strains, with antimicrobial activity. Polymyxin B exerts its antimicrobial effect through its cationic detergent action on cell membranes. Specifically, this antibiotic binds to the neg atively charged site in the lipopolysaccharide layer of the bacterial cell membrane via electrostatic affinity with the positively charged amino groups in the cyclic peptide portion. Subsequently, the fatty acid portion of polymyxin B dissolves in the hydrophobic region of the bacterial cell membrane. This results in an alteration in cell membrane structure, disruption of cell wall integ rity and an increase in permeability for water and molecules. This will eventually lead to bacterial cell death. 